\title{
DELINQUENGY IN RELATION TO THE BROKEN HOME
}

BY

\author{
R. G. GORDON, M.D., D.Sc., F.R.C.P.ED. \\ (From the Bath Child Guidance Clinic.)
}

A considerable interest has recently arisen in the question as to why young people take to crime. To desire to find simple explanations for problems, and to discover rule-of-thumb methods whereby difficulties may be solved is an all too common tendency. It is also true that once such a simple explanation has been found, and such a rule-of-thumb method evolved, the problem loses its fascination and the solution its interest. There is not the least chance of such a loss of fascination and interest in the case of delinquency, for there are no simple explanations and no rule-of-thumb methods of solution. As William Healy emphasized and as many thinkers before him have realized, the delinquent is an individual and must be studied as such, and in the study of delinquency the mistake must not be made of fixing interest on the delinquency to the neglect of the individual who is delinquent. Stealing is probably the commonest delinquency in children, but stealing may be due to a host of causes and may require all sorts of different treatments, and when a young thief is under consideration, it is impossible to say that such and such a set of circumstances have arisen, or that such and such a line of procedure is going to prevent him stealing again. Therefore in presenting a paper on delinquency in relation to the broken home, I wish to explain quite clearly, that I do not regard the broken home as the cause of delinquency, or even perhaps as a cause of delinquency, but merely as a contributory factor among many, all of which have $a$ hand in determining asocial acts. The deliquent must be studied in relation to his environment, and in any situation what contribution he has made and what contribution has been made by the environment have to be considered. It may be taken as axiomatic that both make a contribution, but that in different circumstances the relative value of the two contributions varies. I am inclined to think that if a long series of delinquencies in children be taken, it will be found that the contribution of environment apparently preponderates, and that if it is possible to change the environment in a suitable way, then the individual is capable of adapting to the more suitable environment, and no more trouble ensues. It must be admitted, however, that this may be due to the greater plasticity in adaptation which is enjoyed by the child compared with the adult.

Of all environmental factors, the broken home is recognized as one of the most important, and it is necessary to understand how this factor works. 
First of all what is meant by the broken home? It can be defined as follows: whenever the normal relationship between the father, mother, child or children is disturbed, either by the absence of one or both parents or the intrusion of others into the circle, then the home may be described as broken. Thus, the situation will arise if either parent is dead, divorced or separated, or if step-parents or even step-children or adopted children are introduced into the home. The same situation will arise when the child is subjected to divided loyalties, as for example, when he spends a large part of his time living with an aunt or grandmother and the rest of his time at home with his. parents.

\section{Case records}

The following cases may illustrate the influence of such a broken home.

1. Margaret was thirteen years old when first seen. On examination she was underdeveloped and rickety, with a depressed sternum and knock knees. She was of average intelligence and presented no signs of severe emotional instability except that she suffered from nightmares occasionally; but these were not serious. She was one of three children in the household all by different mothers. The step-mother stated that 'Margaret gets worse every day, she has been stealing from me at home and always telling lies. I don't know what to do. I persuade her in every possible way, she wants to be carried about, she sleeps badly and has nightmares, she takes no notice of what me or her father says.' The school report was good, except that the child was frequently late. The child's explanation of being late from school was that she was so busy doing household work, she could not get there in time. She was asked what she did in the mornings and the following was the story: ' Washed and had a cup of water, laid breakfast for father, made my own bed, picked up ashes and polished grate, washed, cleared and washed up father's breakfast things, polished the table, laid the other breakfast things, made large bed and two small beds, changed and cleaned my shoes, combed my hair, had a cup of hot water, went over the living room floor with the floor duster, prepared and came to school.' Before starting the school day apparently the only breakfast was one cup of cold water and one cup of hot water. This was only the child's unsupported statement and must not be taken too seriously. The father and step-mother referred to their minister of religion for a character. According to him they were poor but admirable people. On closer examination this opinion seemed to be founded on the fact that after the birth of the step-mother's own child, the man had wished to leave her, but the minister had persuaded him to marry her, and since then they could do no wrong. Meanwhile, in spite of assertions from the parents that Margaret was looked after well with loving care, had had everything they could manage to give her, she, a growing girl of rising fourteen, continued to lose weight. As she went on getting thinner, she was taken into hospital for investigation; this proved entirely negative so far as organic disease was concerned, but she gained nine and a half pounds in weight in nine days. The ward sister reported: 'She takes her food well. Is a happy and contented child (before admission was sullen and morose). She made no complaints of either cruelty or deliberate neglect at home, but states that the family is sometimes so late in the morning that there was no time for breakfast.' After discharge, it was arranged that she should have dinners at the school canteen, but in spite of the greatest pains taken in trying to get her there, she soon ceased 
to attend. On enquiry it was found that her father forbade her to go, as he required her at home to do household work. After this even the minister had to admit that the husband continually quarrelled with the wife and wanted to leave her; the home was neglected and Margaret again progressively lost weight. Eventually he pursuaded the father to allow Margaret to go to a residential school. A recent report from this school states: ' Health good, scholastic attainments average--said to be a good girl at school, needs to concentrate more. General intelligence average. Conduct good, on the whole making progress. Is a bright happy girl, general improvement in every way since coming here. She takes kindly to household duties and in all probability will be able to take a post in domestic service when of suitable age.' Such is the story of Margaret, a starved household drudge in a home where there was continual strife. It is scarcely surprising that she stole from her step-mother.

2. Robert, aged seven on first examination, was the illegitimate son of a woman now married to the father of her second son who only achieved legitimacy by two days. The family lived together in poor surroundings in complete disharmony. Robert was evidently a bone of contention between the parents, for they were both anxious to get rid of him, but the mother was the chief mover as she accused him of begging and pilfering on several occasions, and although he no doubt did steal, her statements could by no means always be substantiated. Robert was an unpleasant looking youngster, with defective articulation and obvious adenoids. These were removed but without much effect. His intelligence quotient was 80 , i.e. he was backward but not legally defective. He was in homes during the first six years of his life and only came to live with his mother and step-father after this. The latter made some efforts to control the boy but these were not successful, and there were always outbreaks of bad behaviour. The boy himself was subject to periodic outbursts of temper, accompanied by lying, stealing, truancy and so on. Between these attacks he was only fairly good. In this connexion, it is interesting to record four reports from teachers at about nine-month intervals.

February, 1929. He is amenable to discipline, anxious to please, timid, no moral defects.

November, 1929. Not amenable to discipline, not affectionate, spiteful, destructive, pilfers, has undesirable personal habits.

July, 1931. Not amenable to discipline, not affectionate, spiteful, destructive, bullies, steals, in and out of school, lies, very objectionable in personal habits (exposes himself).

March, 1932. Amenable to discipline, fairly obedient, affectionate, easily led, not destructive, not bad tempered, not aggressive, of rather solitary habits.

From these reports by different teachers is clearly seen that his behaviour is erratic, but there is a definite suggestion that this erratic behaviour may owe something to the influence under which he was living at the time. He was most certainly not wanted at home and was a most unprepossessing child. It was not surprising that he had outbursts of aggression in which he ran counter to everyone. He was eventually brought before the juvenile court for sleeping out for six nights. He was put on probation, but soon broke this and was sent to a residential school.

3. Peggy was the daughter of a school teacher, ambitious that the child should also enter the profession and perfectly conscientious and kind, but perhaps not very devoted to his daughter. Her own mother had died when she was an infant, and for the first nine years of her life, she had lived 
with aimable but elderly grand-parents. Her step-mother was also a teacher and was a conscientious woman, who did her best for the child. Peggy had a few epileptic fits in childhood and was subject to outbursts of temper. She had an intelligence quotient of 107. She gained a scholarship to the secondary school, but was brought to the clinic at the instance of the head mistress when she was fifteen, because she was not getting on, and she did not seem likely to be fitted for the profession of a teacher. She was sullen and morose, would not do the lessons which she did not like. It seemed impossible to appeal to her in any way, and she seemed to have no affection for anyone. Even at this stage a bad prognosis was given. She was of the egocentric epileptic personality, for whom the only appeal is the hedonistic one. That is to say, if a thing hurt her she might be dissuaded from doing it, and if it gave her any real personal pleasure, she might be induced to take an interest and give her mind to it. She was obviously, a person who could never make a teacher, From this time she deteriorated, she lived for herself alone, would do nothing for anyone and became quite impossible. She reduced her parents to despair with her tempers, her sulks and her utter selfishness. The grandparents quite unjustly laid the blame for this state of affairs on the step-mother, so she was sent to them. In six weeks she was back home, having completely worn out and defeated the old people. After this, matters rapidly reached a crisis and she became suicidal, on one occasion swallowing 40 cascara tablets which she had cunningly secreted. Fortunately, she was sick and no great harm was done, but the conclusion was reluctantly reached that the only thing to do was to certify her under the Lunacy Act, although she was only seventeen. This case is quoted in contrast with the preceding two, to illustrate that the broken home even if it exists, is not necessarily the cause of trouble. Here was a child incapable of giving or taking affection and however loving her parents had been, it would have been no different. The trouble was inherent, the blame lying in some antecedent defect of stock, and not with the child's contemporaries.

4. Joan was an illegitimate child living with her mother, step-father and two step-sisters younger than herself. For some time she had been brought up by her aunts, who were peculiarly foolish people, praising her if she was sly or cute or even dishonest, and losing no opportunity of blackguarding the child's mother in her presence. Lately she had left these aunts and gone to live with her mother. She was subject to attacks of wilful disobedience, temper and unkindness to her small step-sisters. She was referred to the clinic by the headmistress of her school, who complained that although she was reasonably quick in school (her I.Q. was 91 per cent.), she was untidy in manual work, and although usually amenable to discipline, was at times spiteful and disobedient. She pilfered small sums of money, both at home and in school. She had gained a scholarship for a senior school, but had failed to maintain this, owing to refusal to work. Physically, she was undersized for her age, and for this reason, unable to maintain her status in games with girls of her own age. In this case, there is no doubt that several influences were at work. Her aunts had prejudiced her against her mother, and had encouraged her in sly, underhand behaviour, such as easily led to pilfering. Her step-father was quite well disposed towards her, but he did not take a great deal of interest in either her or his own children, and although he was quite willing to cooperate, he was foolish and played off the aunts against his wife in the child's regard and on one occasion threatened that the child would go to a lunatic asylum if she did not behave. Joan was definitely jealous of her step-sisters and this sometimes broke out into active bullying. Above all she resented her smallness which she felt kept her among the babies. Treatment consisted in eliminating the foolish 
aunts from her life with the co-operation of father and mother to whom Joan's particular difficulties were explained. She was given thyroid and pituitary gland extract to promote her growth and she not only grew in physical stature, but in self reliance and self respect. After leaving school her mother reported that she was a perfectly normal girl and a real help in the home. The latest report was that she was in work, doing well and giving no trouble.

5. A not dissimilar story, but less satisfactory is that of Dennis a sharp precocious boy with an I.Q. of over 107. He lived part of the time with his father and step-mother, a younger step-brother and sister, and part of the time with his aunt and her friend. At first the main trouble with Dennis was truancy from school, which was largely because he was not sufficiency interested, and the work to which he was set was far too easy. Later however, he got into trouble with his step-mother and was said to have stolen money from her. His father entirely failed to control him and his truancy became serious. It was never easy to get reliable information, his first school authorities were not helpful, largely owing to suspicion that religious prejudice was behind the complaints. The step-mother did not want him and complained of every sort of delinquency and spitefulness directed by the boy against herself and his step-sister. The father was weak and did not exert himself to find a solution. For a time he was sent to stay with an aunt, a well-meaning woman. She was out at work all day and had no love for her sister-in-law-the boy's step-mother. The result was that she had no control of him and as she abused his step-mother in front of this extremely sharp boy, he soon learnt to make capital out of this, and ran home to retail what the aunt said about the step-mother, and then proceeded to the aunt to tell her the counter abuse. Naturally this did not make for peace but the excitement of it all went to the boy's head. School, where his lessons were easy and in no way interested him, could not compete, he truanted more and more and it was obviously only a matter of time until he got into serious trouble. So far as the boy was concerned, there was no particular psychological peculiarity about him, and it seemed reasonable to suppose that if he could only be subject to kindly discipline and control all would be well. The trouble was that the boy was approaching fourteen and after that age could not be sent to a Home Office residential school, which seemed the best solution in the circumstances. In the absence of funds, the only way to achieve this was by bringing him before the courts, but his only crime was truancy, and the only person to accuse him of pilfering was his step-mother, in whose word no one put very much credence. The police, however, found him sleeping out and charged him with wandering. The magistrates agreed to send him to a residential school from which the reports as to his behaviour are at present good, and I have some confidence that he will make good, but with the reservation to which I shall refer later.

\section{Discussion}

It is proposed to review these five cases and consider what contribution the broken home had to make to each. In the first case the home had almost everything to do with the problem for Margaret was an average normal child, when she was not being starved and overworked. In the second case I think the contribution may be held to be about even. Robert had a bad home, he was not wanted and was never cared for, but he certainly was not normal himself. In the first place, he was intellectually backward, but not more so than many other members of society who give no trouble. 
Secondly, he was physically of the adenoidal, rickety type, but again not more so than many other children of his age and station, and thirdly he was subject to periodic outbursts of temper and delinquency, which some are inclined to call epileptic equivalents, without knowing exactly what is meant by this. Yet there is something in the term and this periodicity of abnormal behaviour almost certainly owes something to a constitutional factor, of which the nature is as yet unknown. It may be concluded that it is doubtful if Robert would have made good in any environment, and it is doubtful if the most careful psychological treatment combined with a good environment, would have had much effect.

In the third case, Peggy, there appears to be no doubt. The influence of the broken home was negligible, and in her case there was an inherent incapacity for social adjustment and environment or treatment would have had no beneficial effect, because there was no straw out of which to make bricks. Such a personality frequently goes with epilepsy, and has been called by Pierce Clarke and McCurdy the epileptic personality.

In the fourth case, Joan, there was again a mixed influence. The house and the divided loyalties between aunts and mother were responsible for a good deal, and she was undoubtedly jealous of the step-sisters, who probably really found more favour in her step-father's eyes than she did, though this was not particularly noticeable to the outside observer. A potent factor was her undoubted grievance over her small stature and puny physique, a factor which is commoner and more important in boys than in girls. When this remedied itself in the course of nature and perhaps with the help of the gland preparations, she made a good adjustment.

The fifth case Dennis is one of peculiar interest. Here the home conditions, divided loyalties and jealousies, had a great deal of influence, but here was a boy of more than normal intelligence, full of the spirit of adventure, who found his ordinary surroundings dull and quite insufficient to meet his requirements. He was heading towards making the sort of young criminal who has lately 'keen figuring in the newspapers to a considerable extent; the smash and grab raider, the rioters of Dartmoor and so on. It is hoped that he has been caught young enough and sent to a school where, while subjected to discipline, he may at the same time find occupation to interest him and extend him both mentally and physically.

\section{Remedies}

Let it be clear then that the broken home comes into the story of many delinquents and these five cases have only been taken at random as illustrations, but it must be remembered that there are plenty of children in broken homes who are not delinquent, and plenty of children in homes which are not broken who are delinquent, so that this factor is only one of many. There are many homes which are so unsatisfactory that the children ought to be got out of them. For this purpose the Public Assistance Committee may step in and send the child to one of their cottage homes, or to foster 
parents. If the child enters them quite young, the cottage homes under a good matron are often quite successful, but they are of little use for those who have to be removed from their own homes at a later age. Foster parents sound all right in theory, but in practice the right people do not want strange children, and those who are attracted by the small payment which goes with the child are not as a rule the right people. There remain the various voluntary boys and girls homes, training ships and the residential schools, many of which have some free places. There are not enough of these, however, and it is difficult to get children into them. Some contribution is generally required and it is not usual for the parents in the homes here being discussed to be able or willing to afford this. With regard to the residential schools, the ordinary entrance to these is through the courts. Either the child must be charged with a crime or the parent must come to the courts complaining that the child is out of control. With regard to the latter point many parents are too lazy and indifferent to trouble to do this. Others not without reason feel that it implies a criticism of themselves and are therefore unwilling to take this step. Moreover magistrates are quite rightly chary of relieving a bad parent of all responsibility for his child, and placing this responsibility on the taxpayer. Under the Children's Act there is a clause under which the Education Authority has power to take action and bring a child before the courts. In the circumstances which have been described, and if this power is wisely used and administered, many of the difficulties may be solved. There remains crime as a means of entry to these school, but if the child is to benefit by the residential school, he must be sent there early, and the public are often unwilling to charge a child for petty delinquencies, so that he fails to come before the court until he has done something really bad, which is a culmination of a long series of asocial behaviour. Even so, many magistrates regard this as a first offence and put the child on probation either because they have no knowledge of his social and home surroundings, or in a few cases because the magistrate, though he obtains advice from those who know, rejects it because he thinks that he is being interfered with and that the advisors are trying to teach him his job. Probation is an excellent system in its proper place and under proper conditions, but when the home is quite hopeless and no co-operation can be expected from the parents, the probation officer does not have a chance, and it is not fair to burden him with such cases. 